\title{
EĞİRDİR GÖLÜ DİP SEDİMENTİNDE AĞIR METAL FRAKSIYYONLARININ İNCELENMESİ
}

\author{
Bülent KIRKAN ${ }^{*}$, Hakan ŞENÇIMEN² \\ ${ }^{1}$ Süleyman Demirel Üniversitesi, Su Enstitüsü, Isparta, Türkiye \\ ${ }^{2}$ Süleyman Demirel Üniversitesi, Fen Bilimleri Enstitüsü, Su Bilimleri Anabilim Dalı, Isparta, Türkiye
}

\begin{tabular}{l}
\hline Anahtar Kelimeler \\
\hline Ĕgirdir Gölü, \\
Sediment, \\
Ağır Metal, \\
Ardışlk Ektraksiyon Yöntemi, \\
Risk Değerlendirme.
\end{tabular}

Öz

Eğirdir Gölü'nde kirlilik, özellikle tarımsal aktiviteler bașta olmak üzere insan kaynaklı kirletici etmenler nedeniyle her geçen gün artış göstermektedir. Bu kirlilik kaynaklarının başında ağır metaller önemli bir yer tutmaktadır. Söz konusu kirlilik besin zinciri ile sucul canlılardan insanlara kadar gelebilmektedir. Bu çalışma kapsamında Eğirdir Gölü’nde 8 dip sediment örnekleme istasyonu belirlenmiştir. Alınan dip sediment örneklerinin $\mathrm{pH}$, iletkenlik, organik karbon tayini, karbonat tayini, katyon değişim kapasitesi ve organik madde tayini (\%) gibi bazı fizikokimyasal parametre değerleri belirlenmiştir. Daha sonra dip sediment örneklerinde mevcut $\mathrm{Cd}, \mathrm{Pb}, \mathrm{Cu}, \mathrm{Fe}, \mathrm{Ni}, \mathrm{Mn}, \mathrm{Cr}$ ve $\mathrm{Zn}$ ağır metalleri 4 farklı kimyasal fraksiyona ayrılarak incelenmiştir. Örneklerde mevcut ağır metallerin kimyasal fraksiyonlarına ayrılmasında Avrupa Birliği Referans Komisyonu tarafından geliștirilen BCR (The European Community Bureau of Reference) ardışı ekstraksiyon yöntemi kullanılmıștır. Fraksiyonlara ayrılarak elde edilen çözeltilerde mevcut ağır metal konsantrasyonlarının belirlenmesinde ICP-OES cihazı kullanılmıștır. Elde edilen analiz sonuçlarına göre örnekleme istasyonlarında belirlenen ağır metal miktarları için kirlilik ve ekolojik risk değerlendirmeleri yapılmıștır.

\section{INVESTIGATION OF HEAVY METAL FRACTIONS IN EĞİRDİR LAKE BOTTOM SEDIMENT}

\begin{tabular}{|c|c|}
\hline Keywords & Abstract \\
\hline $\begin{array}{l}\text { Egirdir Lake, } \\
\text { Sediment, } \\
\text { Heavy Metal, } \\
\text { Sequential Extraction Method, } \\
\text { Risk Assessment. }\end{array}$ & $\begin{array}{l}\text { The pollution of Lake Egirdir Lake is increasing day by day due to human-induced } \\
\text { pollutants, especially agricultural activities. Heavy metals have an important place } \\
\text { in these pollution resources. The existing pollution can come from aquatic creatures } \\
\text { to humans with the food chain. In this study, eight bottom sediment sampling } \\
\text { stations were selected in Egirdir Lake. Some physicochemical parameter values } \\
\text { such as pH, conductivity, organic carbon determination, carbonate determination, } \\
\text { cation exchange capacity and organic matter determination (\%) of the sediment } \\
\text { samples were determined. Then, heavy metals of } \mathrm{Cd}, \mathrm{Pb}, \mathrm{Cu}, \mathrm{Fe}, \mathrm{Ni}, \mathrm{Mn}, \mathrm{Cr} \text { ve } \mathrm{Zn} \\
\text { present in bottom sediment samples were separated into } 4 \mathrm{different} \text { chemical } \\
\text { fractions and analyzed. The BCR (The European Community Bureau of Reference) } \\
\text { sequential extraction method developed by the European Community Bureau of } \\
\text { Reference was used in the separation of the heavy metals present in the samples } \\
\text { into chemical fractions. ICP-OES device was used to determine the heavy metal } \\
\text { concentrations present in the solutions obtained by fractionation. According to the } \\
\text { analysis results obtained, pollution and ecological risk assessments were made for } \\
\text { amounts of heavy metals determined at the sampling stations. }\end{array}$ \\
\hline
\end{tabular}

Alıntı / Cite

Kırkan, B., Şençimen, H., (2021). Eğirdir Gölü Dip Sedimentinde Ağır Metal Fraksiyonlarının İncelenmesi, Mühendislik Bilimleri ve Tasarım Dergisi, 9(4), 1224-1235.

\footnotetext{
* ilgili yazar / Corresponding author: bulentkirkan@sdu.edu.tr, +90-246-211-3210
} 


\begin{tabular}{l|l|l}
\hline Yazar Kimliği / Author ID (ORCID Number) & \multicolumn{3}{|l}{ Makale Süreci / Article Process } \\
\hline B. Kırkan, 0000-0003-3462-0681 & Başvuru Tarihi / Submission Date & 21.06 .2021 \\
H. Şençimen, 0000-0003-2397-592X & Revizyon Tarihi / Revision Date & 27.07 .2021 \\
& Kabul Tarihi / Accepted Date & 15.08 .2021 \\
& Yayım Tarihi / Published Date & 20.12 .2021 \\
\hline
\end{tabular}

\section{Giriș (Introduction)}

Son yıllarda dünya nüfusunun katlanarak artması ve teknolojinin hızla ilerlemesiyle birlikte yoğun endüstriyel üretimler sonucunda birçok kirletici madde de çevreyi kirletmektedir. Bu kirletici maddelerin doğrudan veya dolaylı bir şekilde çevreye atılması birçok çevresel problemin oluşumunda büyük bir paya sahiptir. Su kirliliği, su kaynaklarının kimyasal, biyolojik, fiziksel özelliklerini olumsuz yönde kaybetmesine neden olur. Oluşan kirlilik doğal kaynaklarda, insan sağlığında, suyun kalitesinde ve diğer amaçlarla kullanılmasını engellemeye neden olacak şekilde madde veya atıkların boşaltılması sonucu oluşmaktadır (Tumantozlu, 2010). Deniz, göl ve nehir gibi sucul ortamlarda bulunan kirletici maddeler, yeraltı veya yerüstü sularıyla birlikte bu ortamlara deşarj edilerek kirliliğe neden olmaktadırlar. Ağır metaller bu kirleticiler arasında az miktarda olsa bile birçok zarara sebep olabileceğinden dolayı önemli yer edinmektedir. Sulardaki insan kaynaklı ağır metal kirliliği evsel atıklar, endüstriyel atıklar, balıkçılık faaliyetleri ve tarımsal faaliyetlerde kullanılan ilaçlar ve gübreler tarafından oluşturulmaktadır. Farklı kaynaklardan sucul ortamlara taşınan ağır metaller düşük konsantrasyonlarda olması halinde bile çeșitli organik ve inorganik bileşiklerle (hidroksitler, oksitler ve silikatlar) kompleks oluşturarak partikül halinde veya zamanla sediment tabakasına çökelerek su ve sediment ortamında konsantrasyonlarını arttırmaktadırlar (Dora, 2005). Böylece sucul ortamlarda yaşayan canlıların doku ve organlarında birikmesiyle çevre ve sağlık sorunlarının oluşmasına neden olmaktadırlar.

Sediment, sucul ortamda kirletici maddelerin taşınması, inorganik veya organik partiküllerin dibe çökmesiyle meydana gelmektedir. Ağır metaller sucul ortamlara girdiği zaman kısa süre içerisinde asıllı partiküller üzerine tutunmasıyla zamanla çökelerek sedimentte depo edilirler. Bundan dolayı sedimentler yüksek ağır metal yüküne sahiptirler (Dora, 2005). Sedimentler bünyesinde bulundurdukları ağır metalleri sucul ortamın fiziki koşulları ve doygunluk seviyelerine göre tekrar suya salabilirler (Dökmeci, 2005). İlk zamanlarda kirlilikleri üzerinde toplayıp ortamın kirliliğini azaltmış gibi görünse bile sonraki aşamalarda tekrar kirlilik oluşturabilmektedirler. Sediment, birim hacim suda bulunan ağır metal konsantrasyonundan çok daha fazla miktarda ağır metal tutabilir. Bundan dolayı toplam sediment yükünün küçük bir kısmının bile biyolojik ortama alınabilirliği sucul organizmalar açısından dikkate değer bir öneme sahiptir (Kennish, 1997). Sedimentte farklı kimyasal formlarda ağır metaller bulunur ve tutunmalarıda farklılık göstermektedir. Sediment içerisinde mevcut ağır metaller, iyon değişimi yapabilen, karbonat bağlı ve Fe-Mn oksitlere bağll, organik madde ve sülfüre bağlı, silikata bağlı fraksiyonlar olarak beș farklı fraksiyona bölünmüștür (Tessier, 1979). Bu fraksiyonlardan iyon değişimi yapabilen, karbonat bağll, FeMn oksitlere bağlı fraksiyonların sucul ortamlara alınabilirliği yüksek, organik madde ve sülfüre bağlı fraksiyonun alınabilirliği düşük, silikat bağlı fraksiyonun ise alınabilirliği yoktur. Sedimentte bulunan metallerin kimyasal fraksiyonları ortamdaki silikat, hidroksit, oksit, karbonat gibi iyonlar ve organik maddelerle birlikte sedimentin, pH, elektriksel iletkenlik, redoks potansiyeli, katyon değişim kapasitesi, toplam organik madde, kalsiyum karbonat miktarı gibi parametrelere bağlı olarak değişkenlik göstermektedir. Dolayısıyla bu faktörlerinde göz önüne alınarak sedimentte meydana gelen ağır metal birikiminin ve hangi metalin potansiyel olarak su ortamına alınabileceğinin tespit edilmesi sucul ortamlardaki ağır metal kirliliğinin anlaşılabilmesi için önemli bir göstergedir.

Çalışma alanımız olan Eğirdir Gölü Türkiye'nin ikinci en büyük tatlı su gölü olan ve bulunduğu bölgede çok amaçlı kullanılmasından dolayı değerlidir. Eğirdir Gölü’nde özellikle tarımsal aktiviteler başta olmak üzere insan kaynaklı kirletici etmenler nedeniyle kirlilik her geçen gün artmaktadır. Bu kirlilik kaynaklarının başında ağır metaller önemli bir yer tutmaktadır. Söz konusu kirlilik besin zinciri ile sucul canlılardan insanlara kadar gelmektedir. Eğirdir gölünde günümüze kadar su, sediment ve farklı balık örneklerinde mevcut toplam ağır metal miktarlarının belirlenmesi için birçok çalışmalar (Şener, 2010; Kaptan ve Özan, 2014; Bulut, 2015) yapılmıştır. Fakat özellikle dip sedimentinde birikme eğiliminde olan ağır metallerin sediment/su dengesi ardışık ektraksiyon yöntemi kullanılarak farklı fazlarda ve fraksiyonlarda bulunma oranları ve mevcut dağılımın risk faktörleri hakkında değerlendirmeler yapılmamıştır.

Bu tez çalışması kapsamında Eğirdir gölünden alınmış olan dip sediment örneklerinin farklı fraksiyonlarda mevcut ağır metallerin konsantrasyonları Avrupa Birliği Referans Komisyonu tarafından geliştirilen BCR ardışık ekstraksiyon yöntemi kullanılarak belirlenmiştir. Sediment örneklerinin bazı fizikokimyasal parametreleride analiz edilmiştir. Elde edilen istasyonlara göre ağır metal miktarlarının dağılımına göre kirlilik ve risk indeksi değerlendirmeleri yapılmıştır. 


\section{Kaynak Araștırması (Literature Survey)}

Eğirdir gölü ve havzasında farklı dönemlerde su kaynaklarının hidrojeokimyası ve kullanılabilirlik özelliklerinin incelenmesi (Davraz ve Batur, 2020); su, dip sedimenti ve bazı su ürünlerinde (Șener, 2010; Şener vd., 2011; Bulut 2015) ağır metal tayini kapsamında çalışmalar yapılmış olmasına rağmen dip sedimentinin kimyasal fraksiyonlarını ortaya konan bir çalışma yapılmamıștır.

Keskin yapmış olduğu çalışmada (2012), Köyceğiz Gölü’nde üç dönem için beş istasyondan sediment örnekleri almıştır. Sediment örneklerinde fizikokimyasal parametreler yanında sedimet örneklerinde mevcut ağır metallerin kimyasal fraksiyonlarına ayrılmasında BCR yöntemini kullanarak $\mathrm{Cu}, \mathrm{Fe}, \mathrm{Mn}, \mathrm{Ni}, \mathrm{Pb}$ ve $\mathrm{Zn}$ metallerinin kimyasal fraksiyonlarını incelemiştir. Daha sonra her bir metal için risk değerlendirme kodu (RAC) kulanarak metallerin risk seviyeleri ortaya koymuştur. Köyceğiz Gölü sedimentinde Mn ve Pb'nin oldukça yüksek risk oluşturduğu $\mathrm{Cr}$ ve Fe'in herhangi bir risk oluşturmadığı diğer metallerin risk derecelerinin ise aylara ve istasyonlara bağlı olarak değişkenlik gösterdiğini rapor etmiştir.

Pradita ve diğerleri (2019) çalışmalarında BCR sıralı ekstraksiyon yöntemini kullanarak Songkhla gölünden aldıkları sedimentlerde eser elementlerin ( $\mathrm{Zn}, \mathrm{As}, \mathrm{Cd}$ ve $\mathrm{Pb}$ ) konsantrasyonlarını belirlemişlerdir. Asitte çözünür fraksiyonda (F1) Zn (\%37,20-64,42) ve Cd (\%63,44-77,50) baskın olarak bulmuşlardır. İndirgenebilir fraksiyonda (F2) Pb (\%62,01-89,48) baskın olarak tespit etmişlerdir. As (\%49,92-73,45) F2 fraksiyonunda ve \%48,71-68,02 konsantrasyonlarında oksitlenebilir fraksiyonda (F3) baskın olarak bulmușlardır. Bütün eser elementleri (Zn, As, $\mathrm{Cd}$ ve $\mathrm{Pb}$ ) biyolojik olarak temin edilebilir fraksiyonlar olan ilk üç fraksiyonda belirlemişler ve $\mathrm{F} 4$ fraksiyonundaki metal konsantrasyonlarının ise düşük olduğunu rapor etmişlerdir. $\mathrm{Cd}$ elementinin ekolojik risk değerlendirmesinden tüm istasyonlarda bireysel konsantrasyon faktörü (ICF) $>6$ olarak, küresel konsantrasyon faktörünün (GCF) > 24 olduğunu ve risk değerlendirme kodunun ise (RAC) > \%50 olarak sinıflandırıldığını bu değerlerin sudaki organizmalar açısından risk teşkil ettiğini bildirmişlerdir.

Küçüksezgin ve Aydın (2012) Bakırçay ve Gediz Nehirleri havzasında yapmış oldukları çalışmada, sediment örneklerinde ağır metal fraksiyonlarını araștırmışlardır. Çalışmalarında sediment örneklerinde ardışık ekstraksiyon prosedürü kulllanarak $\mathrm{Fe}, \mathrm{Pb}, \mathrm{Zn}, \mathrm{Ni}, \mathrm{Cu}, \mathrm{Mn}, \mathrm{Cr}$ metallerini fraksiyonlara ayırıp konsantrasyonlarını belirlemişlerdir. Elde etmiş oldukları sonuçlara göre $\mathrm{Cr}, \mathrm{Zn}, \mathrm{Cu}$ ve $\mathrm{Ni}$ ağır metallerinin en yüksek miktarda mobil olmayan fraksiyonlarda bulunduğunu, Pb'un daha yüksek yüzdesinin kalıntı ve indirgenebilir fraksiyonda, Mn'ın en yüksek kalıntı ve karbonat fraksiyonlarında, Fe'in ise en yüksek derişimde kalıntı fraksiyonunda olduğunu belirlemişlerdir. Hesaplamış oldukları risk değerlendirme kodlarına göre; $\mathrm{Fe}, \mathrm{Pb}, \mathrm{Zn}, \mathrm{Ni}$, $\mathrm{Cu}$ ve $\mathrm{Cr}$ ağır metallerinin her iki nehir için düşük ve orta derece risk kategorisi arasında olduğu, Mn'ın ise Bakırçay'da yüksek risk, Gediz Nehri'nde orta derecede risk kategorisinde olduğunu belirtmişlerdir.

Şener (2010) Eğirdir gölünde yapmış olduğu çalışmada sediment örneklerinde ağır metal derişimlerini incelemiş ve $\mathrm{Pb}$ metalinin doğal ve antropojenik kaynaklı olup inorganik tarımsal ilaçlardan kaynaklandığını belirlemiştir. $\mathrm{Cu}$ metalinin tarımsal ve endüstriyel kirleticilerden dolayı yüksek konsantrasyonda olduğunu gözlemlemiștir. Ni metalinin tarım ve antropojenik kaynaklı olduğunu tespit etmiştir. Zn metalinin bazı bölgelerde yüksek çıkmasının antropojenik girdilerden kaynaklandığı belirtmiştir. Fe metali özellikle yalvaç deresinin boşaltım noktasında yüksek olduğunu tespit etmiştir. Mn metalinin antropojenik etkilerden ve kayaç-su etkileşiminden dolayı yüksek bulunduğunu belirtmiştir. Cr metalinin ise pupa çayı, çay dere ve yalvaç deresinin boşaltımından kaynaklandığını tespit etmiştir.

Bulut Eğirdir Gölü sedimentinde yapmış olduğu çalış̧mada (2015) Hg, Pb, Cd ve Zn ağır metallerinin derişimlerinin dört eşik etki değerinin altında olduğunu belirlemiştir. As ve Ni metal derişim değerlerinin yüksek çıkmasının jeolojik etkiler ve tarım aktivitelerden kaynaklandığını belirtmiştir.

Li ve arkadaşları (2018) Honghu Gölü'nden yapmıș oldukları çalıșmada sediment örneklerinde BCR yöntemini kullanarak ağır metallerin kimyasal fraksiyonlarını incelemişlerdir. Belirlenen ağır metallerin biyolojik etkilerinin belirlenmesi sonrasında beș metal için $\mathrm{Cr}>\mathrm{Cu}>\mathrm{Zn}>\mathrm{Pb}>\mathrm{Cd}$ sıralamasını elde etmişlerdir. Sediment örneklerindeki ağır metallerin RAC değerlerini $\mathrm{Cd}$ (önemli risk) $>\mathrm{Cu}$ (orta risk) $>\mathrm{Zn}$ (düşük risk) $>\mathrm{Pb}>\mathrm{Cr}$ olarak elde etmişler ve $\mathrm{Cd}$ ve $\mathrm{Cu}$ metalleri yönünden kirlenmenin yüksek riskli olduğunu belirlemişlerdir.

\section{Materyal ve Yöntem (Material and Method)}

\section{1. Çalışma Alanı (The Study Area)}

Çalışma alanımız olan Eğirdir Gölü ülkemizin Akdeniz Bölgesinde yer almaktadır. Ülkemizin en büyük dördüncü, tatlı su olarak ikinci en büyük gölü olmakla birlikte $420 \mathrm{~km}^{2}$ bir alana sahiptir. Eğirdir gölü uydu görüntüsü ve 
örnekleme noktaları Şekil 1'de verilmiştir. Eğirdir Gölü'ndeki derinlikler 5 - 15 m arasında değişmektedir. Eğirdir Gölü havzasında birçok akarsu bulunmaktadır. En çok bilinen akarsular Yalvaç (Sücüllü), Pupa çayı (Üyüllü) ve Gelendost çayıdır. Eğirdir Gölü bulunduğu bölgede çok amaçlı olarak kullanılmaktadır. Bunlar içerisinde ilk sırada bölge halkı için içme suyu kaynağı olması gelmektedir. Daha sonrasında etrafında bulunan birçok tarım arazilerinin sulanması, balıkçılık ve turizm gibi birçok faaliyet gerçekleștirilmektedir. Analiz için gerekli örnekler alınırken Eğirdir Gölü’nde, göle deşarj noktalarına yakın ve kirliliği temsil edebilecek sediment yapısına sahip noktalardan sekiz farklı istasyon seçilmiştir.

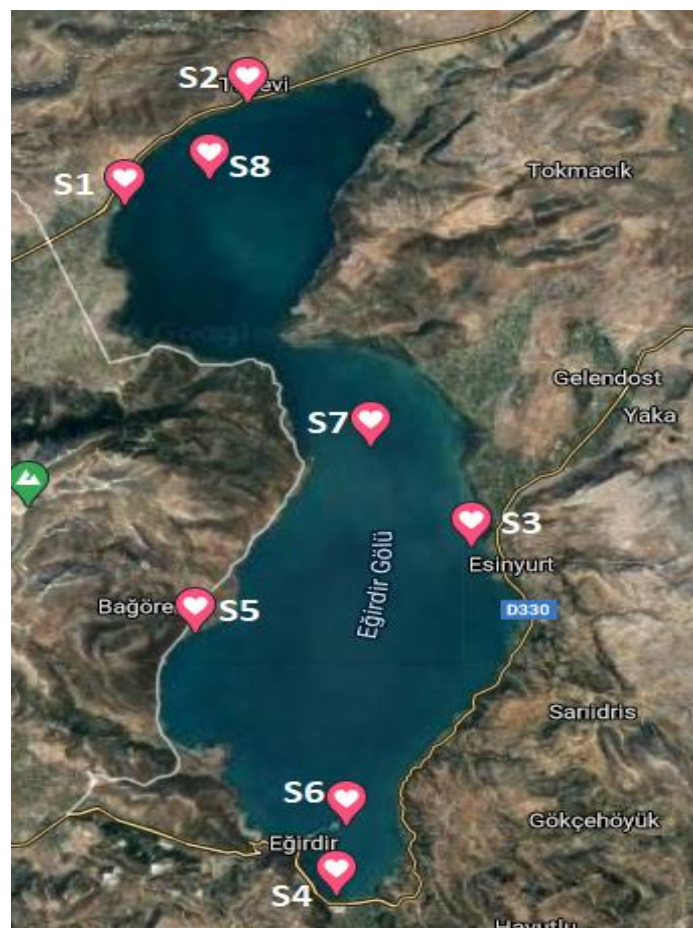

Şekil 1. Çalışma alanı ve istasyonların uydu görüntüsü (Satellite view of workspace and stations)

\section{2. Çalışma Yöntemleri (Methods)}

Belirlediğimiz istasyonlardan sediment örnekleri Eckmann Kepçesi ile alınmış ve 1L'lik plastik kaplara doldurularak laboratuvara getirilmiștir. Bu yöntemle alınmıș olan örnekler sedimentin ilk $10 \mathrm{~cm}$ ' lik kısmının kompozit karışımını temsil etmektedir. Aldığımız sediment örneklerinin fizikokimyasal ölçümleri ve ağır metalleri fraksiyonlarına ayırma işlemleri Süleyman Demirel Üniversitesi Su Enstitüsü Laboratuvarı'nda gerçekleştirilmiştir. Sediment örnekleri kurutulduktan sonra <1mm boyuttaki elekten geçirilerek elenmiştir.

\subsubsection{Sediment örneklerinin fizikokimyasal analiz yöntemleri (Physicochemical analysis methods of sediment samples)}

\subsubsection{1. $\mathrm{pH}$, iletkenlik ( $\mathrm{pH}$, conductivity)}

Sediment-su oranı 1:3 (w/v) olacak şekilde bidestile saf su ile sediment çamur haline getirilerek pH, iletkenlik WTW İnolab cihazı ile ölçülmüştür.

\subsubsection{Karbonat tayini $\left(\% \mathrm{CaCO}_{3}\right)$ (Carbonate determination)}

50,0 mL 0,5 M HCl çözeltisi 5,0 g sediment örneği üzerine eklenip 5 dakika çözelti isıtılmıştır. Yeterli soğukluğa ulaşıncaya kadar beklenip sonrasında sediment-asit karışımı filtre kullanılarak süzülmüş ve asitlik tam olarak giderilinceye kadar kalan çökelti kısmı dört kez 5-10 mL saf su ile yıkama işleminden sonra süzüntüye fenolftalein ekleyip 0,25 M NaOH ile renk değişimi gözleninceye kadar titre edilmiştir (Bech vd., 2008; Keskin, 2012).

\subsubsection{Organik Karbon tayini (Organic Carbon determination)}

0,5 g sediment örneğine 10,0 mL $1 \mathrm{~N} \mathrm{~K}_{2} \mathrm{Cr}_{2} \mathrm{O}_{7}$ eklenerek karıştırılmış ve ardından 20,0 mL derişik $\mathrm{H}_{2} \mathrm{SO}_{4}$ ilave edilerek karıştırılmaya devam edilmiştir. 30 dakika bekleyip soğuduktan sonra, $200 \mathrm{~mL}$ saf su, 10,0 $\mathrm{mL} \mathrm{H}_{3} \mathrm{PO}_{4}$ ve 
3-4 damla (0,025M) ferroin indikatörü ilave edilip, 0,5 $\mathrm{N} \mathrm{FeSO}_{4}$ çözeltisi ile titrasyon işlemi yapılarak tayin edilmiştir (Walkley-Black Metodu; Keskin, 2012).

\subsubsection{Katyon değişim kapasitesi (KDK) (Cation exchange capacity)}

4,0 g sediment örneği santrifüj tüpüne aktarıldıktan sonra 33,0 mL 1N sodyum asetat $\left(\mathrm{NaCH}_{3} \mathrm{COO}\right)$ çözeltisi ilave edildikten sonra tüpün ağzı kapatılarak çalkalanmıştır. Çalkalama işleminden sonra santrifüj işlemi uygulanmıştır. Üst kısımda kalan şeffaf sıvı dökülmüştür ve bu işlem iki kere daha uygulanmıștır. Yıkama işlemi için $33 \mathrm{~mL}$ etil alkol ilave edilerek tüpün ağzı tekrar kapatılarak çalkalanmış sonra santrifüj işlemi uygulanmış ve üstteki şeffaf sıvı dökülmüştür. Bu işlem üç kez tekrar edilmiştir. Daha sonra sedimente 33,0 mL $1 \mathrm{~N}$ amonyum asetat $\left(\mathrm{NH}_{4} \mathrm{CH}_{3} \mathrm{COO}\right)$ ilave edilerek çalkalandıktan sonra santrifüj işlemi uygulanmış ve üstteki şeffaf sıvı $100 \mathrm{~mL}$ lik balon jojede toplanmıștır. Amonyum asetat ilave edilerek iki defa daha aynı ișlem uygulanmıș ve elde edilen sıvılar balon jojede toplanarak amonyum asetat ile $100 \mathrm{~mL}$ ye tamamlanmıştır. Çözeltinin sodyum konsantrasyonu ICPOES cihazında okunarak; meq= $\mathrm{Na}^{+}(\mathrm{mg}) / \mathrm{mol}$ kütlesi $\mathrm{x}$ tesir değerliği formülünden KDK hesaplanmıştır (EPA Method 9081; Keskin, 2012).

\subsubsection{Organik madde tayini (\%) (Determination of organic matter)}

Sabit tartıma getirilmiş porselen kroze içerisine belli miktarda (3-5 g) sediment örneği alınarak ilk tartım yapılmış ve not edilmiştir. Örnekler kül firınında $550{ }^{\circ} \mathrm{C}$ 'de 4 saat yakma işleminden sonra desikatörde soğutulmuş ve sabit tartıma getirilerek son tartım alınıp not edilmiştir. İlk tartım ile son tartım arasındaki farktan \% organik madde tayini yapılmıştır (APHA, 2005; Keskin, 2012).

\subsubsection{Sediment örneklerinde ağır metallerin fraksiyonlara ayrılması ve analizleri (Fractionation and analysis of heavy metals in sediment samples)}

Ağır metallerin fraksiyonlara ayrılmasında genellikle BCR ve Tessier prosedürleri uygulanmaktır. BCR prosedürü, Tessier'in önerdiğine göre farklı olarak ağır metal fraksiyonlarını; değişebilir ve asitte çözünebilen (karbonata bağlı), indirgenebilir (Fe-Mn oksihidroksitlere bağlı), oksitlenebilir (organik maddelere ve sülfürlere bağll) ve kalıntı (silikatlara bağlı) fraksiyonlar olarak dört basamakta değerlendirilmektedir. Fraksiyonlara ayırma işlemine geçmeden önce sediment örneklerinde mevcut ağır metallerin analizi yaptırılmış ve örneklerde belirlenmiş olan ağır metallerin fraksiyonlara göre dağılımı incelenmiştir. Bu işlem için dip sediment örneklerinden 1,0'er g alındı ve BCR ardışık kimyasal ekstraksiyon prosedürü uygulanarak ağır metaller fraksiyonlarına ayrıldı. Her örnek için fraksiyonlarına ayırma işlemi 3 tekrarlı olarak gerçekleștirilmiş ve elde edilen çözeltiler birleștirilmiștir. Ardından elde edilen çözeltilerde mevcut ağır metal miktarları ICP - OES cihazı ile analiz edilmiştir (Keskin, 2012).

\subsubsection{Değișebilir fraksiyon (F1) (Exchangeable fraction)}

1,0 g dip sediment örneği santrifüj tüpüne aktarılmış ve üzerine $40,0 \mathrm{~mL} 0,11 \mathrm{M} \mathrm{CH}_{3} \mathrm{COOH}$ çözeltisi eklenmiştir. Oluşan karışım 16 saat oda sıcaklığında çalkalanmıştır. Ekstraktant santrifüj işlemi uygulanarak katı fazdan ayrılmış ve polietilen saklama kabına konarak $(50 \mathrm{~mL})$ analiz gerçekleştirilinceye kadar buzdolabında bekletilmiştir. Santrifüj tüpünde kalan katı kısım 20,0 mL saf su ile 15 dakika çalkalanarak yıkama işlemi uygulanmış ve santrifüj edildikten sonra yıkama suyu atılmıştır. Ardından bir sonraki fraksiyon basamağına geçilmiştir (Keskin, 2012).

\subsubsection{2. İndirgenebilir fraksiyon (F2) (Reducible fraction)}

İlk basamaktan elde edilen santrifüj tüpündeki katı kısma 40,0 mL 0,5 M NH $\mathrm{N}_{2} \mathrm{OH}$.HCI çözeltisi ilave edilmiştir. Ardından elde edilen karışım 16 saat oda sıcaklığında çalkalayıcıda çalkalanmıştır. Çalkalama işleminden sonra 15 dakika santrifüj işlemi uygulanmıştır. Elde edilen çözelti polietilen saklama kabına konarak analiz gerçekleştirilinceye kadar buzdolabında bekletilmiștir. Santrifüj tüpünde kalan katı kısım ilk basamakta olduğu gibi yıkama işleminin ardından sonraki basamak için hazır hale getirilmiştir (Keskin, 2012).

\subsubsection{Oksitlenebilir fraksiyon (F3) (Oxidizable fraction)}

İkinci basamaktan elde edilen katı kısma $10,0 \mathrm{~mL}$ 8,8 $\mathrm{M} \mathrm{H}_{2} \mathrm{O}_{2}$ çözeltisi ilave edilmiştir. Ardından santrifüj tüpünün kapağı kapatılarak çözünürleştirme için $22{ }^{\circ} \mathrm{C} 60$ dakika çalkalanmıştır. Çözünürleştirme işlemine tüplerin kapakları açılarak 60 dakika boyunca $85 \pm 2{ }^{\circ} \mathrm{C}$ 'de su banyosunda devam edilmiştir. Sonrasında santrifüj tüplerinde çözelti hacmi 3,0 mL'den az kalana kadar devam edilmiştir. İşlem tamamlandığında 8,8 $\mathrm{M} \mathrm{H}_{2} \mathrm{O}_{2}$ çözeltisinden ikinci bir $10,0 \mathrm{~mL}$ ilave edilmiş ve tüplerin kapakları kapatılarak tekrar $85 \pm 2{ }^{\circ} \mathrm{C}$ 'de 60 dakika ısıtılmıştır. Daha sonra tüplerin kapakları açılarak çözelti hacmi 1,0 mL kalana kadar buharlaştırmaya devam 
edilmiştir. Bu kısımda çökeltinin kurumamasına dikkat edilmiştir. Santrifüj tüpleri soğutulduktan sonra üzerine $50,0 \mathrm{~mL} 1 \mathrm{M} \mathrm{NH} \mathrm{CH}_{3} \mathrm{COO}$ çözeltisi ilave edilmiş ve 16 saat $22 \pm 5{ }^{\circ} \mathrm{C}$ çalkalanmıştır. Ekstraktant santrifüj uygulanarak katı fazdan ayrılmış ve polietilen saklama kabına konarak analiz gerçekleştirilinceye kadar buzdolabında bekletilmiştir. Kalan katı kısım daha önceki basamaklarda olduğu gibi yıkanama işlemi uygulanarak bir sonraki aşama için hazır hale getirilmiştir (Keskin, 2012).

\subsubsection{Kalıntı fraksiyon (F4) (Residual fraction)}

En son ardışık ekstraksiyonlardan her örnek için elde edilen numuneler birleştirilerek içerisinde kalan ağır metallerin miktarlarının analiz edilmesi için ICP-OES cihazı laboratuvarına verilmiştir.

\section{Araştırma Bulguları (Research Findings)}

\subsection{Sediment Örneklerinin Fizikokimyasal Özellikleri (Physicochemical Properties of Sediment Samples)}

Sediment örnekleri içerisindeki ağır metallerin dağılımlarını fizikokimyasal koşullar ciddi seviyede etkilemektedir. $\mathrm{Bu}$ parametrelerden en önemlisi $\mathrm{pH}$ parametresidir. $\mathrm{pH}$ ölçülmesi ile sedimentin salınımı ve birikimleri kontrol edilmektedir. Ağır metallerin mobilitesi sediment içerisinde pH’ın düşmesi ile arttığından dolayı sucul ortama salınım gerçekleştirme riski yüksektir (Peng vd., 2009; Keskin 2012; Wang vd. 2020). İstasyonlardan alınan dip sediment örneklerinin fizikokimyasal analiz sonuçları Tablo 1' de verilmiştir.

Tablo 1. Alınan örneklerin istasyonlara göre fizikokimyasal parametrelerin analiz sonuçları (Analysis results of physicochemical parameters of the samples taken according to the stations)

\begin{tabular}{|c|c|c|c|c|c|c|}
\hline İstasyon No & $\mathbf{p H}$ & $\begin{array}{c}\text { İletkenlik } \\
(\boldsymbol{\mu S} / \mathbf{c m})\end{array}$ & $\mathbf{\% C a C O}_{\mathbf{3}}$ & $\mathbf{\%}$ Organik C & $\begin{array}{c}\text { \%Organik } \\
\text { Madde }\end{array}$ & $\begin{array}{c}\text { KDK } \\
\text { (meq/100g) }\end{array}$ \\
\hline S1 & 8,1 & 147,5 & 24,7 & 1,58 & 5,35 & 18,3 \\
\hline S2 & 7,9 & 186,2 & 24,9 & 1,42 & 2,37 & 4,3 \\
\hline S3 & 8,7 & 96,6 & 23,8 & 0,74 & 5,51 & 21,3 \\
\hline S4 & 8,1 & 215,0 & 24,1 & 1,80 & 5,31 & 17,9 \\
\hline S5 & 8,9 & 83,2 & 23,8 & 1,25 & 1,37 & 4,6 \\
\hline S6 & 7,7 & 245,0 & 24,6 & 2,67 & 10,31 & 35,2 \\
\hline S8 & 8,4 & 163,4 & 24,7 & 1,91 & 5,43 & 16,0 \\
\hline
\end{tabular}

$\mathrm{Bu}$ çalışma ile yapılan ölçümler sonucunda pH değerleri 7,76 - 8,81 aralığında değiştiği tespit edilmiştir. Bu sonuçlara göre dip sedimentinde bulunan ağır metallerin sulu ortama salınımlarının kısıtlı olacağı düşünülmektedir. İletkenlik, tuzluluğun bir başka ifadesi olarak değerlendirilebilir ve metallerin sediment içerisinde metal dağılımlarını etkilemektedir. Sediment örneklerinin yapılan iletkenlik ölçüm sonucu 83,2 - 245,0 $(\mu \mathrm{S} / \mathrm{cm})$ aralığında olduğu belirlenmiştir ve elde edilen sonuçlar bir içme suyu kaynağı olarak kullanılan Eğirdir gölü için sediment içerisinde çözünmüş iyonların miktarının düşük olması ile bağlantılı olduğu düşünülmektedir. Dip sediment örnekleri için belirlenen iletkenlik değerleri literatürde benzer çalışmalarda da elde edilmiștir (Ates vd., 2020). Elde edilen sonuçlarda $\% \mathrm{CaCO}_{3}$ değerleri \%23,8 - 24,9 aralığında değişim gösterdiği belirlenmiștir. Organik maddeye bağlı olan oksitlenebilir fraksiyonun açıklanması açısından \% organik $\mathrm{C}$ ve \% organik madde miktarları büyük önem taşımaktadır. Yapılan ölçümler sonuncunda \% organik C miktarı \% 0,74 - 3,19 aralığında, $\%$ organik madde miktarı ise \%1,37 - 10,31 aralığında olduğu tespit edilmiştir. Katyon değişim kapasitesi sedimentin birim miktarda adsorplayabileceği katyon miktarını ifade etmektedir. Yapılan çalışma sonucunda KDK değerleri 4,3 - 35,2 meq/100g aralığında değiștiği tespit edilmiştir.

\subsection{Ağır Metal Fraksiyonların Yüzde Dağılımı (Percentage Distribution of Heavy Metal Fractions)}

Ağır metallerin çevresel etkilerini değerlendirmek için ağır metallerin fraksiyonlarının belirlenmesi büyük önem arz etmektedir. Çünkü toplam ağır metal konsantrasyonu ile yalnızca sedimentlerin kalitesi değerlendirilebilirken ağır metallerin fraksiyonlarının konsantrasyonunun tespit edilmesi ile metallerin potansiyel riskleri ve mobiliteleri hakkında bilgi edinilebilmektedir. Aşağıda BCR ardışık kimyasal ekstraksiyon yönetimi kullanılarak belirlenen $\mathrm{Cr}, \mathrm{Cu}, \mathrm{Fe}, \mathrm{Mn}, \mathrm{Ni}, \mathrm{Pb}$ ve $\mathrm{Zn}$ metallerinin fraksiyonlarının istasyonlar arasındaki yüzde dağılımları Şekil 2-8'de verilmiş ve her bir metal için ayrı ayrı değerlendirmeler yapılmıştır. 


\subsubsection{Bakır (Cu) (Copper)}

Elde edilen analiz sonuçlarına göre 8 istasyondan alınan örneklerden sadece S4 no'lu istasyonda değişebilir fraksiyon miktarı \%0,6 olarak; S1, S2, S3, S4, S5 no'lu istasyonlarda ise indirgenebilir fraksiyon miktarı \%30,567,2 arasında; S6 no'lu istasyonda oksitlenebilir fraksiyon miktarı \%44,3 ve tüm istasyonlarda kalıntı fraksiyonu miktarları \%32,8 - 100 aralığından tespit edilmiștir. Bakır metali için bakıldığında en yüksek konsantrasyonların indirgenebilir ve kalıntı fraksiyonlarında olduğu tespit edilmiştir. Bu durum doğal kaynaklar dışında antropojenik kaynaklı kirleticilerin göle deşarj edildiğini göstermektedir. Bakır için indirgenebilir fraksiyona bağlı fraksiyonun ilk beş istasyon için yüksek mobilite ve potansiyel riske sahip olduğunu göstermektedir. Bakır metali için LOQ (tayin limiti) değeri 6 g/L' dir. İstasyonlara göre Cu ağır metalinin fraksiyonlara göre yüzde dağılımı Șekil 2'de verilmiştir.

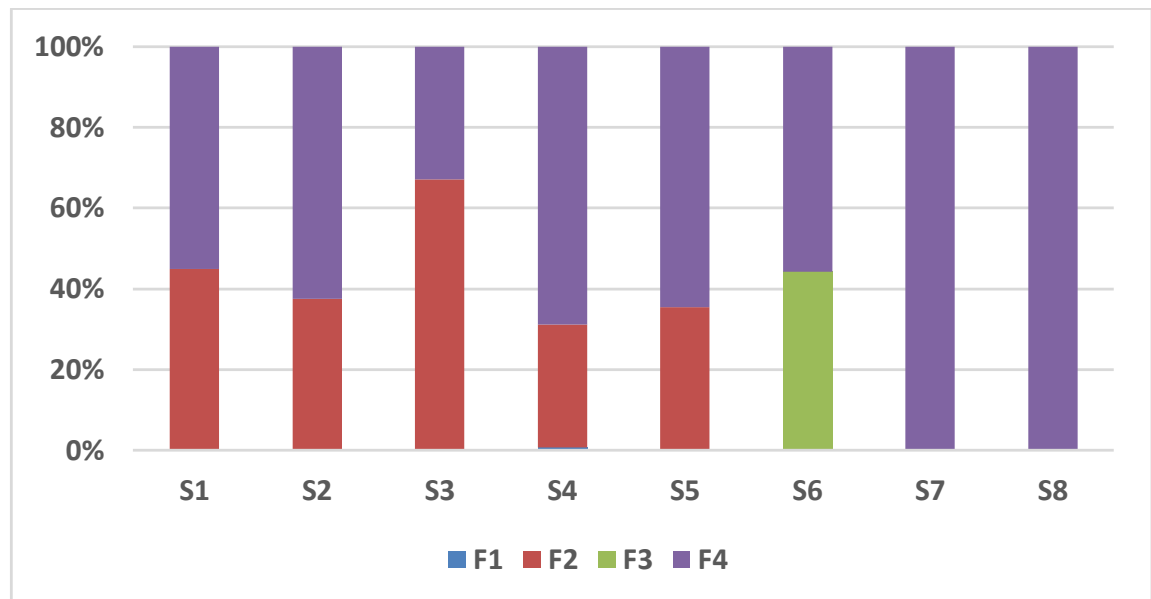

Şekil 2. Cu metali fraksiyonlarının istasyonlar arasındaki yüzde dağılımı (Percentage distribution of Cu metal fractions between stations)

\subsection{2. Çinko (Zn) (Zinc)}

Elde edilen analiz sonuçlarına göre 8 istasyondan alınan örneklerde değișebilir fraksiyon, indirgenebilir fraksiyon ve oksitlenebilir fraksiyonlarında Zn metali belirlenememiștir. S1, S5, S6, S7 no'lu istasyonlarda mevcut Zn metalinin tümü kalıntı fraksiyonunda tespit edilmiştir. Söz konusu istasyonlar için bu durum Zn ağır metalinin doğal kaynaklı olduğunu göstermektedir. Çinko metali için LOQ değeri 6 mg/L' dir. İstasyonlara göre Zn ağır metalinin fraksiyonlara göre yüzde dağılımı Şekil 3'de verilmiştir.

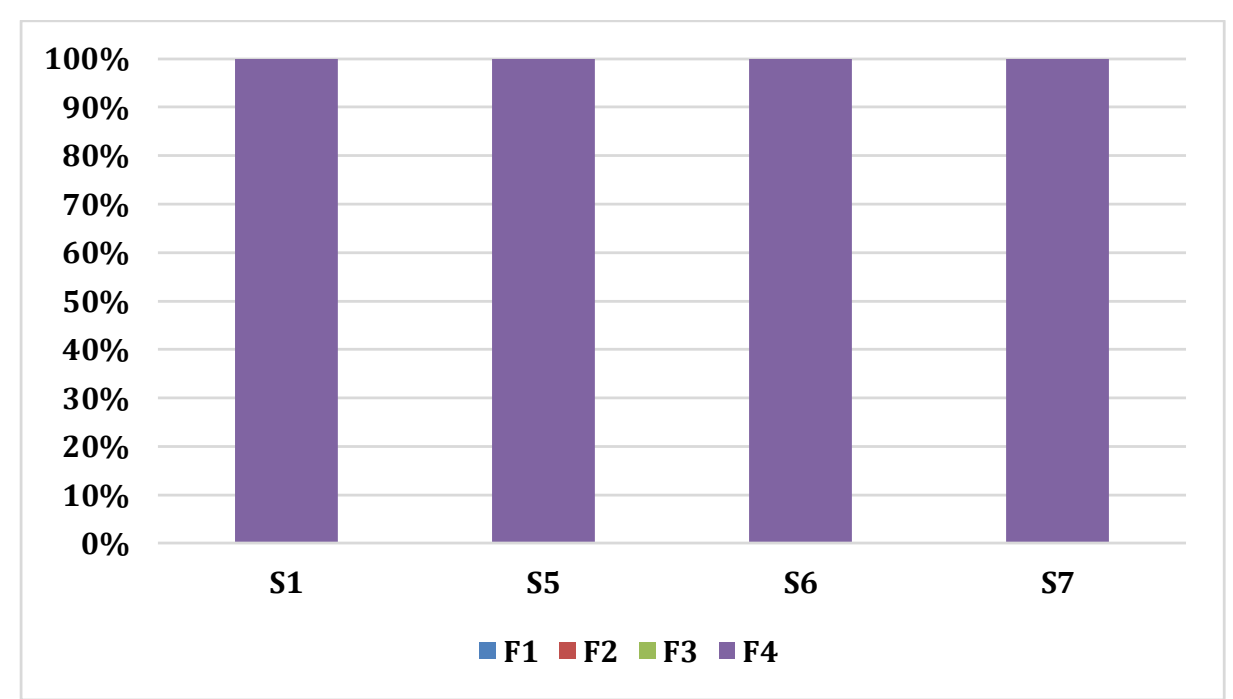

Şekil 3. Zn metali fraksiyonlarının istasyonlar arasındaki yüzde dağılımı (Percentage distribution of Zn metal fractions between stations)

\subsubsection{Demir (Fe) (Iron)}

Elde edilen analiz sonuçlarına göre S1, S2, S4, S5, S6 istasyonlarından alınan örneklerde değișebilir fraksiyon miktarı \%0,04 - 2,8 aralığında değişirken; S3, S7, S8 no'lu istasyonlarda ise belirlenememiştir. İndirgenebilir fraksiyon miktarları \%0,3 - 8,4 olarak ilk beș istasyonda tespit edilmişken diğer istasyonlarda tespit 
edilememiştir. Oksitlenebilir fraksiyon miktarı \%0,1 - 3,1 arasında S5 ve S6 istasyonlarında tespit edilmişken, diğer istasyonlarda ise tespit edilememiştir. Tüm istasyonlar için kalıntı fraksiyon miktarı \%88,8 - 100 aralığında değiştiği tespit edilmiştir. Bu sonuçlara göre Fe metali için değişebilir, indirgenebilir ve oksitlenebilir fraksiyon miktarlarının düşük olması nedeniyle önemli derecede potansiyel risk içermediği belirlenmiştir. Kalıntı fraksiyon miktarlarının yüksek yüzdelere sahip olması ise Fe metalinin doğada çok fazla miktarda bulunması ve yağmur suları, erozyonlar gibi doğal süreç sonucu sucul ortama taşınıp sediment içerisinde biriktiği düşünülmektedir. Demir metali için LOQ değeri $15 \mu \mathrm{g} / \mathrm{L}^{\prime}$ dir. İstasyonlara göre Fe ağır metalinin fraksiyonlara göre yüzde dağılımı Şekil 4'de verilmiştir.

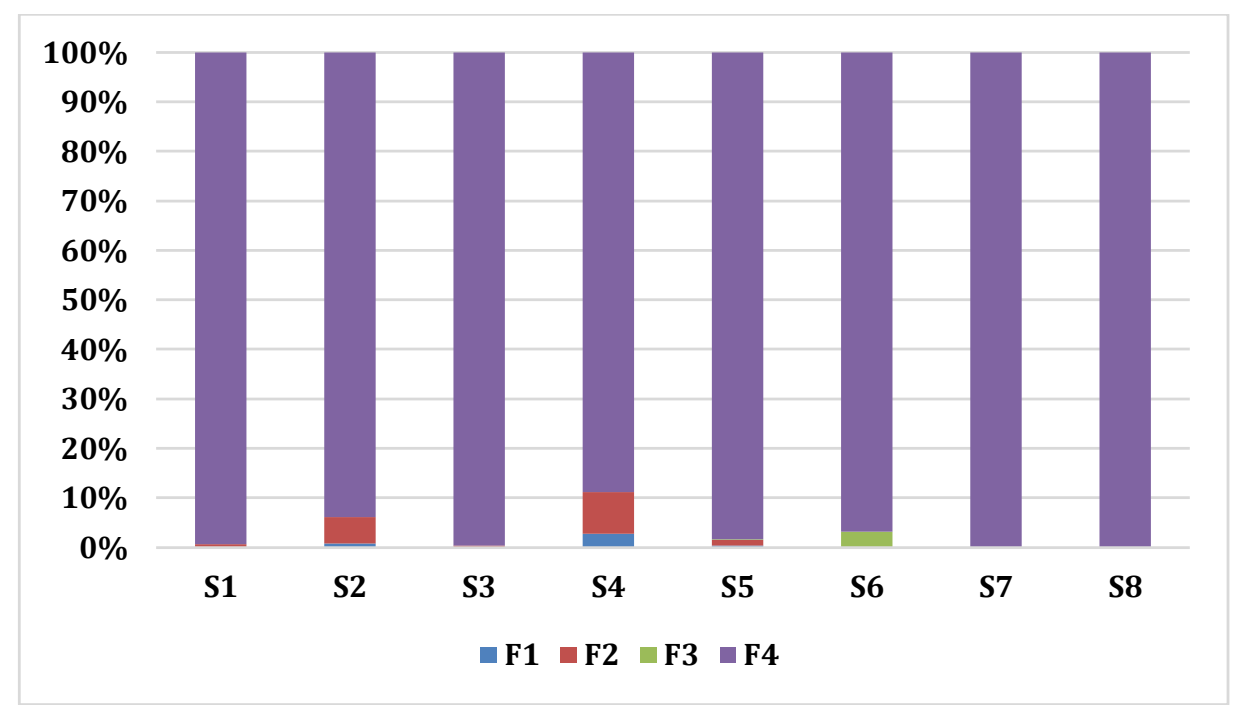

Şekil 4. Fe metali fraksiyonlarının istasyonlar arasındaki yüzde dağılımı (Percentage distribution of Fe metal fractions between stations)

\subsubsection{Mangan (Mn) (Manganese)}

Elde edilen analiz sonuçlarına göre 8 istasyondan alınan örneklerde değișebilir fraksiyon miktarları \%2,1 - 47,7 aralığında, indirgenebilir fraksiyon miktarları \%3,0 - 26,3 aralığında, oksitlenebilir fraksiyon miktarları \%1,1 26,3 aralığında olduğu tespit edilmiştir. S8 no'lu istasyon örneğinde ise ilk üç fraksiyonda Mn metaline rastlanmamıștır. Tüm istasyonlar için sediment örneklerinde kalıntı fraksiyon miktarları \%23,1-100 arasında değiștiği belirlenmiștir. Mn değișebilir ve indirgenebilir fraksiyon yüzdesi yüksek olduğu için potansiyel risk oluşturduğu ve organizmalar için biyokullanılabilir olabileceği belirlenmiştir. Ayrıca mobil fraksiyon yüzdelerinin yüksek olması Mn kaynaklarının antropojenik kaynaklı olduğu ve bölgede yoğun yapılan tarımsal aktivitelerden kaynaklandığı düşünülmektedir. Mangan metali için LOQ değeri 5 g/L' dir. İstasyonlara göre Mn ağır metalinin fraksiyonlara göre yüzde dağılımı Şekil 5'de verilmiştir.

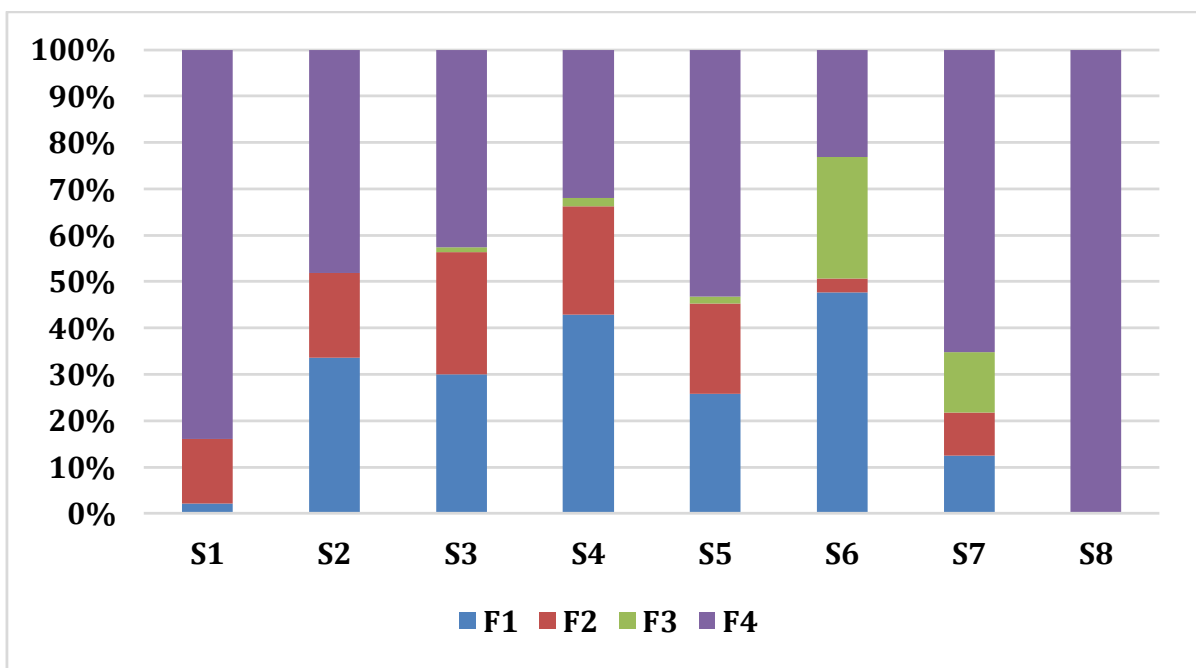

Şekil 5. Mn metali fraksiyonlarının istasyonlar arasındaki yüzde dağılımı (Percentage distribution of Mn metal fractions between stations) 


\subsubsection{Krom (Cr) (Chromium)}

Elde edilen analiz sonu çlarına göre S1, S2 ve S3 istasyonlarında krom metali tespit edilememiștir. Diğer istasyonlar için değişebilir fraksiyonda krom elementi tespit edilemezken, sadece S6 istasyonunda \%0,8 miktarında indirgenebilir fraksiyon elde edilmiștir. Oksitlenebilir fraksiyon miktarları \%2,1 - 2,7 aralığında değișmektedir. Kalıntı fraksiyon yüzdesi ise 97,3 - 100 arasında tespit edilmiştir. Cr metali için ilk üç fraksiyon miktarları genel olarak düşük olduğu için potansiyel risk oluşturmadığı tespit edilmiş̦tir. Krom metali için LOQ değeri $4 \mu \mathrm{g} / \mathrm{L}^{\prime}$ dir. İstasyonlara göre Cr ağır metalinin fraksiyonlara göre yüzde dağlımı Șekil 6’de verilmiştir.

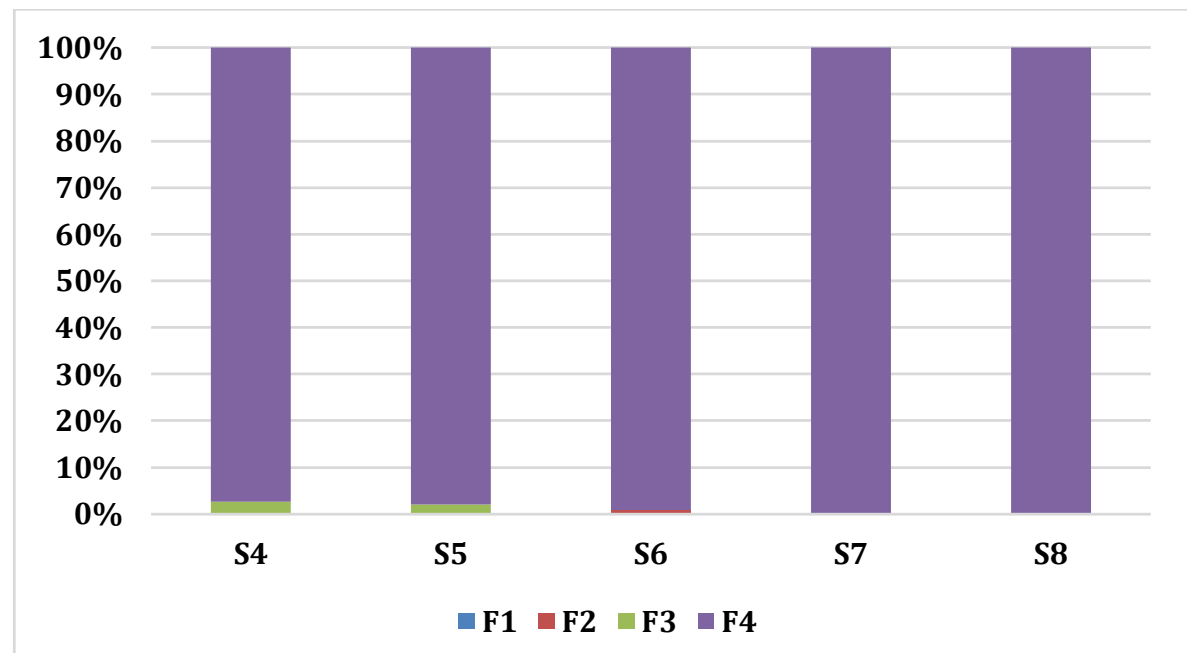

Şekil 6. Cr metali fraksiyonlarının istasyonlar arasındaki yüzde dağılımı (Percentage distribution of Cr metal fractions between stations)

\subsubsection{Nikel (Ni) (Nickel)}

Elde edilen analiz sonuçlarına göre sadece S6 istasyonunda değișebilir fraksiyon miktarı \%2,8 ve oksitlenebilir fraksiyon miktarı \%14,8 olarak tespit edilmiştir. Tüm örneklerde indirgenebilir fraksiyonlarda $\mathrm{Ni}$ metali belirlenememiştir. Kalıntı fraksiyon miktarları ise \%82,4 - 100 aralığında belirlenmiștir. Nikel metalinin farklı fraksiyon miktarları incelendiğinde çoğunlukla kalıntı fraksiyonunda kaldığı için potansiyel risk olușturmadığı belirlenmiștir. Nikel metali için LOQ değeri $8 \mu \mathrm{g} / \mathrm{L}$ ' dir. İstasyonlara göre Ni ağır metalinin fraksiyonlara göre yüzde dağılımı Şekil 7'de verilmiştir.

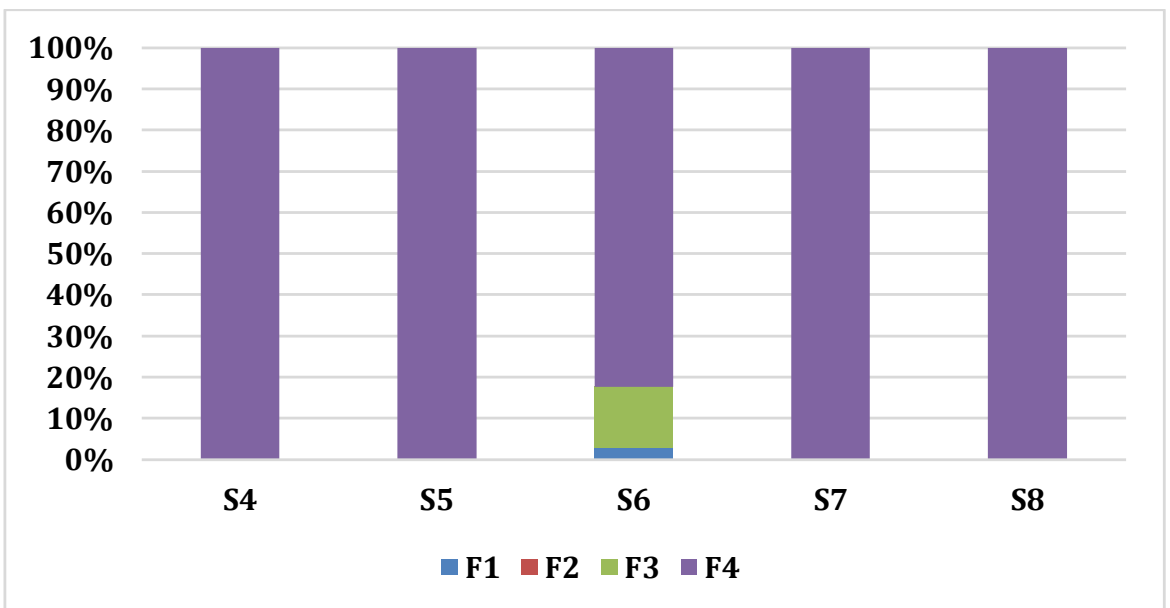

Şekil 7. Ni metali fraksiyonlarının istasyonlar arasındaki yüzde dağılımı (Percentage distribution of Ni metal fractions between stations)

\subsubsection{Kurşun (Pb) (Lead)}

Elde edilen analiz sonuçlarına göre sadece S3 istasyonunda $\mathrm{Pb}$ metali belirlenmiştir. Buna göre değișebilir fraksiyon miktarı \%2,8; indirgenebilir fraksiyon miktarı \%3,9; oksitlenebilir fraksiyon miktarı \%2,2 ve kalıntı fraksiyon miktarı \%91,1 olarak tespit edilmiştir. Elde edilen veriler sonucunda $\mathrm{Pb}$ metalinin mobilitesinin ve potansiyel riskinin düşük olduğu belirlenmiştir. Kurşun metali için LOQ değeri $3 \mu \mathrm{g} / \mathrm{L}$ ' dir. İstasyonlara göre Pb ağır metalinin fraksiyonlara göre yüzde dağılımı Şekil 8'de verilmiştir. 


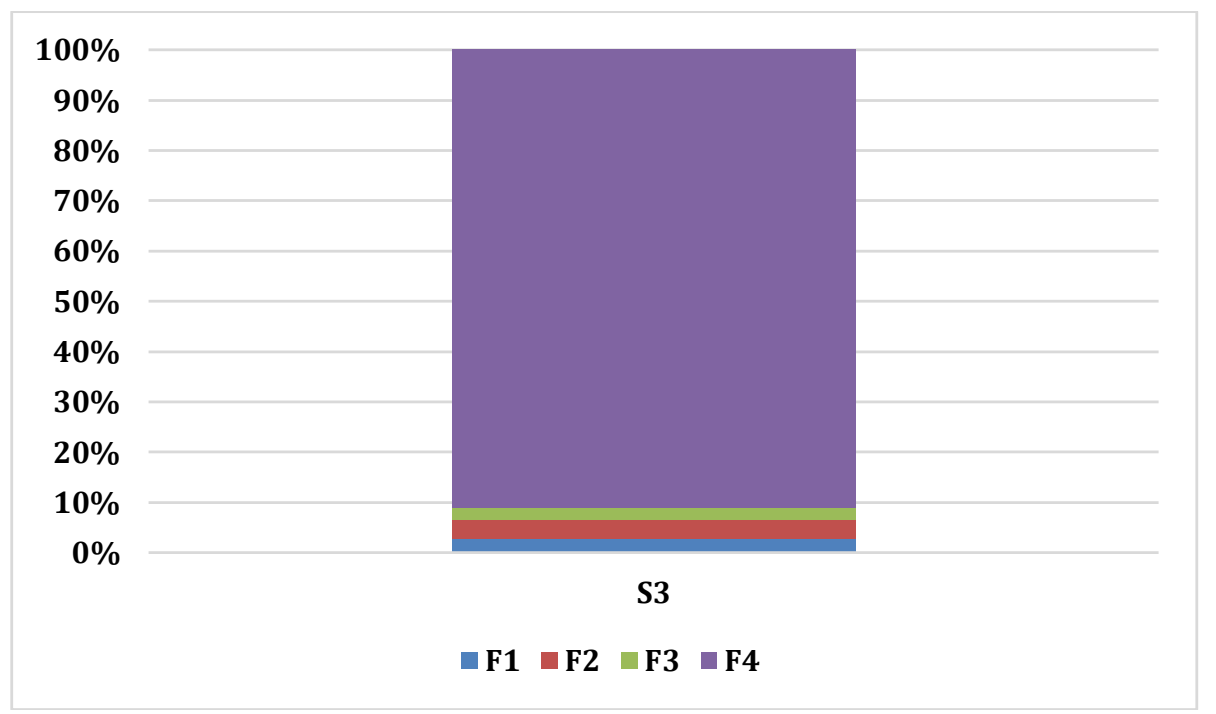

Șekil 8. Pb metali fraksiyonlarının istasyonlar arasındaki yüzde dağlımı (Percentage distribution of Pb metal fractions between stations)

\subsection{Kirlilik ve Ekolojik Risk Değerlendirmesi (Pollution and Ecological Risk Assessment)}

\subsubsection{Risk Değerlendirme Kodu (RAC) (Risk Assessment Code)}

RAC, Tessier ardışık kimyasal ekstraksiyon prosedürü kullanıldığında değişebilir fraksiyon ile karbonata bağlı fraksiyonun, BCR prosedürü kullanıldığında yalnızca değișebilir fraksiyonun (\% F1) toplam miktarının, toplam metal konsantrasyonu içerisindeki yüzdesi esas alınarak metallerin risk değerlendirmesinde kullanılan bir kriterdir. Değișebilir fraksiyon yüzde konsantrasyonlarına göre risk dereceleri Tablo 2'de verilmiștir (Muller, 1981; Keskin, 2012).

Tablo 2. RAC'a göre sınıflandırılmış risk düzeyleri (Risk levels classified according to RAC)

\begin{tabular}{|c|c|}
\hline $\begin{array}{c}\text { Değişebilir fraksiyon miktarı } \\
\text { (\% F1) }\end{array}$ & Risk Derecesi \\
\hline$<1$ & Risk Yok \\
\hline $1-10$ & Düşük risk \\
\hline $11-30$ & Orta derecede risk \\
\hline $31-50$ & Yüksek derecede risk \\
\hline$>50$ & Aşırı derecede yüksek risk \\
\hline
\end{tabular}

Değișebilir fraksiyon yüzde dağılımı her metal için esas alınarak risk değerlendirme kodları hesaplanıp, risk değerlendirmesi yapılmıștır. Buna göre belirlenen istasyonlardan alınan örneklerde $\mathrm{Zn}$ ve $\mathrm{Cu}$ metallerinin risk oluşturmadığı tespit edilmiştir. Fe metalinin $S 4$ no'lu istasyonda düşük risk oluşturduğu $(\% 2,8)$, diğer tüm istasyonlar için risk oluş̧turmadığı $(\%<1)$ belirlenmiştir. Mn metalinin S1 no'lu istasyonda düşük risk oluşturduğu $(\% 2,1)$, S2 no'lu istasyonda yüksek derece risk (\%33,6), S3 no'lu istasyonda yüksek derece risk $(\% 30,0)$, S4 no'lu istasyonda yüksek derece risk (\%42,8), S5 no'lu istasyonda orta derece risk (\%25,8), S6 no'lu istasyonda yüksek derece risk (\%47,7), S7 no'lu istasyonda orta derece risk (\%12,4) ve S8 no'lu istasyonda risk olușturmadığı tespit edilmiştir. Tüm istasyonlar için $\mathrm{Cr}$ metalinin risk oluşturmadığı tespit edilmiştir. Ni metali S6 no'lu istasyonda düşük derece risk $(2,8)$ oluştururken diğer tüm istasyonlarda risk oluşturmadığı tespit edilmiştir. Pb metalinin ise sadece S3 no'lu istasyonda düşük risk derecesine $(\% 2,8)$ sahip olduğu belirlenmiștir.

\subsubsection{Metale göre kirlilik faktörleri (Pollution factors to metal)}

Sediment örneklerinde incelenen metallerin tutulmasını incelemek için, ilk üç fraksiyonun toplamını her istasyon için kalıntı fraksiyonuna oranından ağır metale göre kirlilik faktörleri (ICF) hesaplanmıştır (Soliman vd., 2018; Pradita vd., 2019). Her bir istasyon için küresel kirlilik faktörü (GCF), her istasyonda incelenen ağır metaller için elde edilen ICF'nin toplanmasıyla hesaplandı. ICF ve GCF kirlilik sınıflandırma değerlendirme kriterleri Tablo 3'de verilmiştir. 
Tablo 3. ICF-GCF'e göre kirlilik sinıflandırılması (Pollution classification according to ICF-GCF)

\begin{tabular}{|c|c|}
\hline ICF-GCF & Kirlilik Değerlendirmesi \\
\hline ICF $<1$ & Düşük Kirlilik \\
$\mathrm{GCF}<6$ & Orta Kirlilik \\
\hline $1<\mathrm{ICF}<3$ & \\
$\mathrm{GCF}<12$ & Önemli Kirlilik \\
\hline $3<\mathrm{ICF}<6$ & \\
$12<\mathrm{GCF}<24$ & Yüksek Kirlilik \\
\hline $\mathrm{ICF}>6$ & \\
$\mathrm{GCF}>24$ & \\
\hline
\end{tabular}

Elde edilen metallere göre ICF değerleri Tablo 4'de verilmiştir. Tablo incelendiğinde Cu metali S3 no'lu istasyonu için orta kirlilik sınıfında ve tüm diğer istasyonlarda ise düşük kirliliğe sahip olduğu gözlenmiștir. Mn metali S3 ve S4 no'lu istasyonlarda orta kirliliğe ve S6 no'lu istasyon önemli kirliliğe sahipken, diğer tüm istasyonlarda düşük kirlilik sınıfına girdiği gözlemlenmiştir. Tüm istasyonlarda $\mathrm{Cr}, \mathrm{Zn}$, Fe, $\mathrm{Ni}$ ve $\mathrm{Pb}$ metallerinin ise tüm istasyonlarda düşük kirliliğe sahip olduğu belirlenmiştir.

Tablo 4. Metallere göre ICF kirlilik değerleri (ICF pollution values by metals)

\begin{tabular}{|c|c|c|c|c|c|c|}
\hline İstasyon & $\mathbf{C u}$ & $\mathbf{F e}$ & $\mathbf{M n}$ & $\mathbf{C r}$ & $\mathbf{N i}$ & $\mathbf{P b}$ \\
\hline $\mathbf{S 1}$ & 0,82 & 0,01 & 0,19 & 0 & 0 & 0 \\
\hline S2 & 0,60 & 0,07 & 1,07 & 0 & 0 & 0 \\
\hline $\mathbf{S 3}$ & 2,05 & 0,01 & 1,34 & 0 & 0 & 0,10 \\
\hline S4 & 0,45 & 0,13 & 2,13 & 0,03 & 0 & 0 \\
\hline S5 & 0,55 & 0,02 & 0,88 & 0,02 & 0 & 0 \\
\hline S6 & 0,80 & 0,03 & 3,34 & 0,01 & 0,11 & 0 \\
\hline S7 & 0 & 0 & 0,53 & 0 & 0 & 0 \\
\hline S8 & 0 & 0 & 0 & 0 & 0 & 0 \\
\hline
\end{tabular}

Elde edilen istasyonlara göre GCF değerleri Tablo 5'de verilmiştir ve bu değerlere göre tüm istasyonlarda küresel kirlilik faktörü GCF<6 olması nedeniyle tüm istasyonların düşük kirlilik seviyesine sahip oldukları belirlenmiştir.

Tablo 5. İstasyonlara göre GCF kirlilik değerleri (GCF impurity values by stations)

\begin{tabular}{|l|c|c|c|c|c|c|c|c|}
\hline İstasyon & S1 & S2 & S3 & S4 & S5 & S6 & S7 & S8 \\
\hline GCF & 1,02 & 1,74 & 3,49 & 2,73 & 1,47 & 4,28 & 0,53 & 0 \\
\hline
\end{tabular}

\section{Sonuç ve Tartışma (Result and Discussion)}

Çalışma alanı genel olarak incelendiğinde fizikokimyasal parametreler açısından elde edilen değerlerin normal seviyelerde olarak gözlemlendiği belirlenmiştir. Dip sediment örneklerinin içerisindeki ağır metal dağılımları incelediğinde bazı bölgeler dışarıdan ekstra yoğun antropojenik kirleticilerin girdiği sonucuna ulaşılmaktadır. BCR ardışık ekstraksiyon yöntemi kullanılarak 4 farklı fraksiyonda mevcut ağır metallerin bağlanma durumları, miktarı ve doğal kaynaklı veya insan faaliyetleri kaynaklı olduğunun analiz sonuçlarına göre yorumlanabileceği belirlenmiştir. Elde edilen ağır metal konsantrasyonlarına göre dip sedimentinden kaynaklı kirlilik ve ekolojik risk değerlendirmeleri yapılabilmektedir. Değişebilir fraksiyon yüzde dağılımı her metal için esas alınarak risk değerlendirme kodları hesaplanıp, risk değerlendirmesi yapılmıştır. Örnekleme istasyonlarından elde edilmiş olan fraksiyonlara göre metal miktarı değerlerine göre $\mathrm{Zn}, \mathrm{Cu}$ ve $\mathrm{Cr}$ metallerinin risk oluşturmadı fakat $\mathrm{Fe}, \mathrm{Mn}, \mathrm{Ni}$ ve $\mathrm{Pb}$ metallerinin ise bazı örnekleme istasyonları için farklı derecelerde risk oluşturdukları belirlenmiştir. Metallere göre ICF değerlerine göre $\mathrm{Cu}$ metali S3 no'lu istasyonu için orta kirlilik sınıfında, Mn metali S3 ve S4 no'lu istasyonlarda orta kirliliğe ve S6 no'lu istasyon önemli kirliliğe sahipken, diğer tüm istasyonlarda tüm metallerin düşük kirliliğe sahip olduğu belirlenmiștir. Elde edilen istasyonlara göre GCF değerlerine göre ise tüm istasyonlarda küresel kirlilik faktörü GCF $<6$ olması nedeniyle düşük kirlilik seviyesine sahip oldukları belirlenmiştir.

\section{Çıkar Çatışması (Conflict of Interest)}

Yazarlar tarafından herhangi bir çıkar çatışması beyan edilmemiştir. No conflict of interest was declared by the authors. 


\section{Kaynaklar (References)}

APHA, AWWA, WEF, 2005. Standart Methods For The Examination Of Water And Wastewater, 21st Edition, American Public Health Association, Washington, 4-103 - 4-169.

Ates, A., Demirel, H., Mergul, N., 2020. Risk Assessment and Chemical Fractionation of Heavy Metals by BCR Sequential Extraction in Soil of the Sapanca Lake Basin, Turkey, Pol. J. Environ. Stud. Vol. 29, No. 2 (2020), 1523-1533.

Bech, J., Tume P., Longan, L., Reverter, F., Tempio, M., 2008. Concentration Of Cd, Cu, Pb, Zn, Al And Fe İn Soils Of Manresa, NE Spain, Environ. Monit. Assess., 145: 257-266.

Bulut, C., 2015. Eğirdir Gölü ve Göldeki Bazı Su Ürünlerinde Ağır Metal Düzeyleri ile Stres Parametrelerinin Araştırılması, Süleyman Demirel Üniversitesi, Fen Bilimleri Enstitüsü, Doktora Tezi, Isparta.

Davraz, A., Batur, B., 2020. Yalvaç-Gelendost (Isparta) Havzası Su Kaynaklarının Hidrojeokimyası ve Kullanılabilirlik Özelliklerinin Belirlenmesi, Mühendislik Bilimleri ve Tasarım Dergisi 8(4), 1072 - 1085.

Dora, E.Ç., 2005. İzmir Körfezi'nde Bazı Poliket Türleri (Hediste Diversicolor, Diopatra Neapolitana) ile Bunların Yașadı̆̆ Sedimentte Ağır Metal Düzeylerinin Araştırılması, Ege Üniversitesi, Doktora Tezi, 190s, İzmir.

Dökmeci, H.A., 2005. Gala Gölü ve Gölü Besleyen Su Kaynaklarında Ağır Metal Kirliliğinin Araştırılması, Trakya Üniversitesi, Yüksek Lisans Tezi, 115s, Edirne. elements in sediments of Baiyangdian Lake, China, Science of the Total Environment 724, 138046, 1-8

Kaptan, H., Özan, S.T., 2014. Eğirdir Gölü'nün (Isparta) Suyunda, Sedimentinde ve Gölde Yaşayan Sazan'ın (Cyprinus carpio L., 1758) Bazı Doku ve Organlarındaki Ağır Metal Düzeylerinin Belirlenmesi, SDU Journal of Science (E-Journal), 9 (2): $44-60$.

Kennish, N.J., 1997. Practical Handbook Of Eustuarine And Marine Pollution, Heavy Metals, Chapter 6 (253-327), Florida.

Keskin, F., 2012. Köyceğiz Gölü Sedimentinde Ağır Metal Fraksiyonlarının İncelenmesi, Muğla Sıtkı Koçman Üniversitesi, Fen

Bilimleri Enstitüsü, Yüksek Lisans Tezi, Muğla.

Küçüksezgin, F., Aydın, S., 2012. Distribution And Chemical Speciation Of Heavy Metals İn The Surficial Sediments Of The Bakırcay And Gediz Rivers, Eastern Aegean, Environ. Earth Sci., 65:789-803.

Li, F., Xiao, M., Zhang, J., Liu, C., Qiu, Z., Cai, Y., 2018. Spatial Distribution, Chemical Fraction And Fuzzy Comprehensive Risk Assessment Of Heavy Metals İn Surface Sediments From The Honghu Lake, China, International Journal Of Environmental Research And Public Health, 15(2), 207-218.

Muller G., 1981. The Heavy Metal Pollution Of The Sediments Of Neckars And İts Tributary: A Stocktaking, Chem. Zeit, 105:157164.

Peng, J., Song, Y., Yuan, P., Cui, X., Qui, G.,2009. The remediation of heavy metals contaminated sediment, Journal of Hazardous Materials, 161: 633-640.

Pradita, S., Shazili, N.A.M., Pattaratumrong, M. S., Chotikarn, P., Yucharoen, M., Prawit, T., 2019. Chemical fractionation of trace elements in mangrove sediments from the Songkhla Lake, Thailand using BCR technique, Science Asia, 45, 465-473.

Soliman, N.F., El Zokm, G.M., Okbah, M.A., 2018. Risk assessment and chemical fractionation of selected elements in surface sediments from Lake Qarun, Egypt using modified BCR technique, Chemosphere, 191, 262-271.

Șener, Ș., 2010. Eğirdir Gölü ve Dip Sedimanlarının Hidrojeokimyasal İncelenmesi, Süleyman Demirel Üniversitesi, Fen Bilimleri Enstitüsü, Doktora Tezi, Isparta.

Şener, Ş., Elitok, Ö., Șener, E., Davraz, A., 2011. An Investigation of Mn Contents in Water and Bottom Sediments from Eğirdir Lake, Turkey, Mühendislik Bilimleri ve Tasarım Dergisi, 1:3, 145-149.

Tessier, A., Campbell, P.G.C., Bisson, M., 1979. Sequential Extraction Procedure Fort He Speciation Of Particulate Trace-Metals, Anal. Chem., 51: 844-851.

Tumantozlu, H., 2010. Karacaören II Baraj Gölü'ndeki Su, Sediment ve Sazan (Cyprinus Carpio L., 1758) Örneklerinde Bazı Ağır Metal Birikiminin İncelenmesi. Süleyman Demirel Üniversitesi, Yüksek Lisans Tezi, 54s, Isparta.

Wang, J., Zeng, X., Xu, D., Gao, L.,Li, Y., Gao, B., 2020. Chemical fractions, diffusion flux and risk assessment of potentially toxic 